\title{
Mathematical modeling in the Urumari micro-watershed using Streeter-Phelps mathematical models and the enhanced Do-Bod model
}

\begin{abstract}
When a certain load of pollutants is dumped in urban surface waters, the natural hydrological parameters are altered and a consequent dispersion of a contaminant occurs. Water selfpurification is a natural recovery mechanism that aims to restore the natural parameters of water quality. In the municipality of Santarém, the Urumari micro-watershed, one of the main urban streams and a tributary of the Amazon river, suffers from increasing degradation. Thus, it is necessary to systematically monitor the water quality of the micro-watershed, through mathematical modeling, in order to identify environmental impairment and propose mitigating tools that facilitate self-purification capacity. The aim of this work was to evaluate the degree of disturbance of the Urumari micro-watershed using Streeter-Phelps mathematical models and the Enhanced DO-BOD model. The software Curve Expert 1.4 was used to adjust the coefficients of the mathematical models, using the Levenberg-Marquardt nonlinear function adjustment method. The complete mathematical model of DO and BOD considered the parcels of punctual deficit, microbial BOD, nitrification, sediment demand, photosynthesis and respiration. Three coefficients of the Streeter-Phelps model and six coefficients of the Enhanced DOBOD model were adjusted according to the experimental data of dissolved oxygen and water travel time. The mathematical models satisfactorily correlated the experimental data. The values of the correlation coefficient, mean absolute deviations and quadratic deviations are for the Streeter-Phelps model and the Enhanced DO-BOD model, respectively. The Streeter-Phelps model presented the best correlation to the experimental data with the values of R2 equal to 0.83 ; mean absolute deviation equal to 0.56 and quadratic deviations equal to 4.98 .
\end{abstract}

Keywords: BOD/DO model; Self-depuration; Streeter-Phelps; Ecological model; Water quality model.

\section{Modelagem matemática na microbacia do Urumari utilizando modelos matemáticos de Streeter-Phelps e Od-Dbo aprimorado}

\begin{abstract}
Quando uma certa carga de poluentes é despejada nas águas superficiais urbanas, são alterados os parâmetros hidrológicos naturais, ocorrendo uma dispersão dos poluentes consequentemente causando sua poluição. A autopurificação da água é um mecanismo de recuperação natural que visa restaurar os parâmetros naturais da qualidade da água. No município de Santarém, a microbacia do Urumari, um dos principais córregos urbanos e afluente do rio Amazonas, sofre com o aumento da degradação. Assim, é necessário monitorar sistematicamente a qualidade da água da microbacia, por meio de modelagem matemática, a fim de identificar prejuízos ambientais e propor ferramentas mitigadoras que facilitem a capacidade de autopurificação. O objetivo deste trabalho foi avaliar o grau de perturbação da microbacia do Urumari usando modelo os matemáticos Streeter-Phelps e o modelo matemático aprimorado de DO e BOD. O software Curve Expert 1.4 foi utilizado para ajustar os coeficientes dos modelos matemáticos, utilizando o método de ajuste de função não linear de Levenberg-Marquardt. O modelo matemático aprimorado de DO e DBO considerou as parcelas de déficit pontual, DBO microbiana, nitrificação, demanda de sedimentos, fotossíntese e respiração. Três coeficientes do modelo Streeter-Phelps e seis coeficientes do modelo aprimorado de DO e DBO foram ajustados de acordo com os dados experimentais de oxigênio dissolvido e tempo de viagem na água. Os modelos matemáticos correlacionaram satisfatoriamente os dados experimentais. Os valores do coeficiente de correlação, desvios médios absolutos e desvios quadráticos são para o modelo de Streeter-Phelps e o modelo aprimorado de DO e DBO, respectivamente. O modelo Streeter-Phelps apresentou a melhor correlação com os dados experimentais com os valores de R2 iguais a 0,83; desvio médio absoluto igual a 0,56 e desvio quadrático igual a 4,98.
\end{abstract}

Palavras-chave: Modelo OD/DBO; Auto-depuração; Streeter-Phelps; Modelo ecológico; Modelo de qualidade da água.

Topic: Engenharia de Recursos Hídricos

Reviewed anonymously in the process of blind peer.
Received: 02/10/2020

Approved: 24/11/2020
Lucinewton Silva de Moura (iD

Universidade Federal do Oeste do Pará, Brasil

http://lattes.cnpq.br/2577499231565227

http://orcid.org/0000-0002-9266-946X

lucinewton.moura@yahoo.com.br

Ruy Bessa Lopes (iD)

Universidade Federal do Oeste do Pará, Brasil

http://lattes.cnpq.br/4195469692527946

http://orcid.org/0000-0002-4806-8835

ruybessa@yahoo.com.br

Joseph Simões Ribeiro (iD

Universidade Federal do Oeste do Pará, Brasil

http://lattes.cnpq.br/1888011247908339

http://orcid.org/0000-0001-9715-816X

josephribeiro@hotmail.com

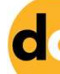

DOI: $10.6008 / C B P C 2179-6858.2020 .006 .0027$

\author{
Graciene do Socorro Taveira Fernandes (iD) \\ Universidade Federal do Oeste do Pará, Brasil \\ http://lattes.cnpq.br/9121021285937589 \\ http://orcid.org/0000-0002-2710-4251 \\ gracienefernandes@hotmail.com \\ Rodolfo Maduro Almeida (iD) \\ Universidade Federal do Oeste do Pará, Brasil \\ http://lattes.cnpq.br/1527651015984510 \\ http://orcid.org/0000-0003-4564-825X \\ rodolfomaduroalmeida@gmail.com \\ Sérgio Gouvêa de Melo (D) \\ Universidade Federal do Oeste do Pará, Brasil \\ http://lattes.cnpq.br/0148689717369496 \\ http://orcid.org/0000-0002-6946-6672 \\ sergiomeloccm@hotmail.com
}

\section{Referencing this:}

MOURA, L. S.; LOPES, R. B.; RIBEIRO, J. S.; FERNANDES, G. S. T.; ALMEIDA, R. M.; MELO, S. G.. Mathematical modeling in the Urumari micro-watershed using Streeter-Phelps mathematical models and the enhanced Do-Bod model. Revista Ibero Americana de Ciências Ambientais, v.11, n.6, p.332-345, 2020. DOI:

http://doi.org/10.6008/CBPC2179-6858.2020.006.0027 


\section{INTRODUCTION}

Urban rivers are highly vulnerable to pollution due to their role of assimilating municipal sewage loads and surface runoff, generated by disordered use and occupation along the watershed (PRAJAPATI et al., 2016; ZHANG et al., 2020). The sewage services in Brazil, especially in the Amazon region, causes water insecurity and alteration of aquatic environments (ARAGÃO et al., 2018; YOSHIl et al., 2019). Regarding the current situation, the state of Pará has 144 municipalities and only 1 of them has collection and treatment of $5 \%$ of the daily sewage load (ANA, 2017). Locally, the municipality of Santarém has a sewage network that extends for $50 \mathrm{~km}$ without a collection network and sewage treatment plants, which puts pressure on the quality of urban water collection, depressing its socioenvironmental services. Among the different liabilities caused by urban water pollution, there is oxygen depletion (PETERS et al., 2000), decrease in water transparency as a result of suspended particulate matter (organic matter), microbiological contamination (CARDOSO et al., 2018), simplification of aquatic environments (biodiversity reduction) and eutrophication (ANTUNES et al., 2020).

On the other hand, watercourses have an environmental stress control mechanism, which allows a maximum responsiveness from which the environment is still responsive. According to Mendes (2010), the self-purification of water bodies and their aquatic environments is a natural process, in which polluting loads, of organic origin, released into a water body are neutralized in a space-time dynamic.

The increasing use of applied mathematical models that can translate the behavior of variables in surface waters, especially urban ones, is important in the face of the loads of pollutants in the aquatic environment (CUNHA et al., 2006; GUO et al., 2019; TEODORO et al., 2013), and they can be used to predict future scenarios. Therefore, mathematical models can be used for instructing management actions that support decisions related to the functional perenniality of environmental services, offered by urban waters. The use of mathematical models ensures data reliability and it instructs management actions supporting decisions related to functional perenniality of environmental services, offered by urban waters (FAN et al., 2009; MANNINA et al., 2010; GHAHRAMANI et al., 2020; LONG, 2020). It is through mathematical modeling that we can represent reality or a simplified and widespread translation of what appears to be the most important characteristics of a real-world situation.

This study consists in the evaluation of the surface water quality of the Urumari micro-watershed in Santarém. It aims to monitor and simulate future scenarios, using a Streeter-Phelps mathematical model and the complete mathematical model of dissolved oxygen (DO) and biochemical oxygen demand (BOD), for prediction of critical time, critical distance and critical DO that allow identifying impairments caused to the environment and the degree of micro-watershed pollution of Urumari.

\section{MATERIALS AND METHODS}

\section{Study area}

This study was conducted in a densely populated urban watershed, in its middle and upper portions, 
with its riparian vegetation completely removed in these portions. The main channel of the watershed has the main spring located southeast of the urban perimeter of Santarém, Pará and the mouth on the Amazon river. The watershed is delimited by the coordinates with longitude of $54^{\circ} 40^{\prime} 34.68^{\prime \prime}$ and $54^{\circ} 43^{\prime} 23.16^{\prime \prime}$ West and latitude $2^{\circ} 30^{\prime} 54.00^{\prime \prime}$ and $2^{\circ} 25^{\prime} 48.00^{\prime \prime}$ South. The watershed faces the reality of the lack of sewage collection network and, therefore, there is numerous irregular domestic sewage connections disorderly placed throughout its main channel. Previously, the area was georeferenced with GPS (ex-Trex 10 Garmin model). Then, the design of the watercourses, area and altitude was elaborated with the free software QGIS, version 2.16.0, from the data of the shuttle radar topographic mission (SRTM). The watershed (Figure 1) has a terrain that varies between the plane and the slightly wavy, with an average altitude of 66 meters, the average width of the basin is $2.5 \mathrm{~km}$ and its total length is $9.47 \mathrm{~km}$. Its drainage area is $22.26 \mathrm{~km}^{2}$ and runs 15 neighborhoods of the municipality. The extension of the watershed main channel is $7.56 \mathrm{~km}$. The average speed along the main channel of one year was determined at $0.18 \mathrm{~m} / \mathrm{s}$, while the average depth was $60 \mathrm{~cm}$.

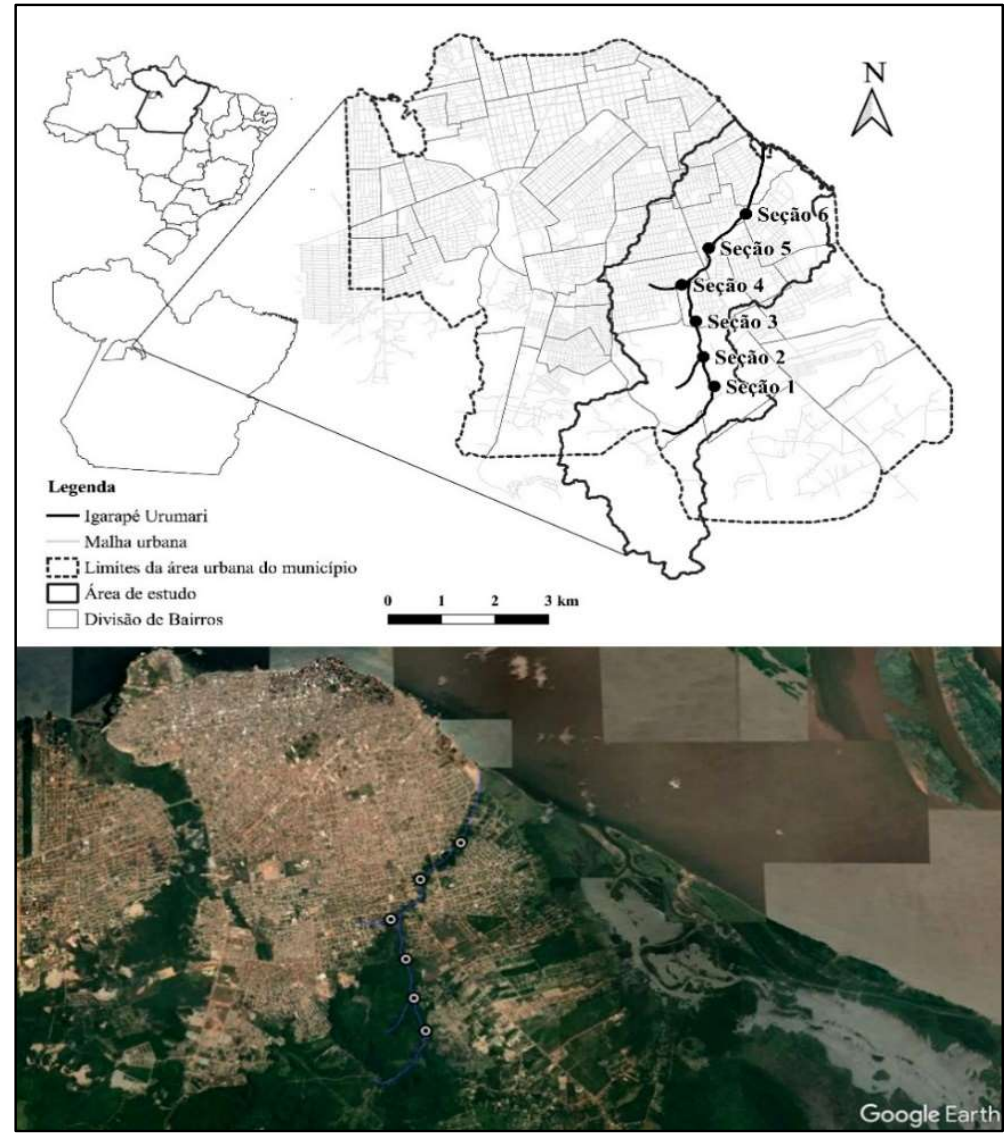

Figure 1: Geographical delimitation of the watershed considering the: boundaries of the municipality area, division of neighborhoods and identification of the sampling sections of the study area.

\section{Sampling sections}

Six sections along the watershed (Figure 1) were selected as sampling sections, based on some criteria, such as, choosing one point upstream and one downstream of the main channel and inclusion of intermediate points in the vicinity of pollution sources. Between the sampling sections, the equidistance of about 800 meters was maintained, except between sections 1 and 2 where this distance was 1600 meters, this was justified due to a greater evidence of the degradation zone from sewage emissions in the main 
channel, considering the significant distribution of clandestine waste discharges, as mentioned above. The distribution of the sections occurred along $5.61 \mathrm{~km}$ of the main channel of the watershed. All sampling sections were georeferenced as shown in Table 1. All collections were performed in duplicate. Oxygen samples were taken on site with an YSI 55 A oximeter.

Table 1: Geographic positioning, distance and altimetry of the watershed sampling sections.

\begin{tabular}{|c|c|c|c|c|}
\hline Sampling sections & Distance (km) & Altimetry (m) & Latitude (S) & Longitude (W) \\
\hline Section 1 & 0.00 & 54.50 & $02 \div 28^{\prime} 46.5^{\prime \prime S}$ & $54 \div 41^{\prime} 47.5^{\prime \prime} \mathrm{W}$ \\
\hline Section 2 & 1.39 & 37.88 & $02^{\circ} 28^{\prime} 38.06^{\prime \prime S}$ & $54^{\circ} 42^{\prime} 0.73^{\prime \prime} \mathrm{W}$ \\
\hline Section 3 & 2.46 & 29.21 & $02^{\circ} 28^{\prime} 4.28^{\prime \prime S}$ & $54^{\circ} 41^{\prime} 59.73^{\prime \prime} \mathrm{W}$ \\
\hline Section 4 & 3.13 & 26.79 & $02 \div 27 ' 38.1 " \mathrm{~S}$ & 54은'07.9"W \\
\hline Section 5 & 4.48 & 8.92 & $02^{\circ} 27^{\prime} 15.62^{\prime \prime S}$ & $54^{\circ} 41^{\prime} 51.17^{\prime \prime} \mathrm{W}$ \\
\hline Section 6 & 5.61 & 44.20 & $02^{\circ} 26^{\prime} 52.25^{\prime \prime S}$ & $54^{\circ} 41^{\prime} 28.54^{\prime \prime} \mathrm{W}$ \\
\hline
\end{tabular}

\section{Mathematical models}

\section{Streeter-Phelps mathematical model}

Streeter et al. (1925) established the mathematical basis of the dissolved oxygen curve in a watercourse. The structure of the model proposed by them is classic within Environmental Engineering, serving as support for all other more sophisticated models that followed. For a relatively simple situation in which only deoxygenation and atmospheric reaeration in the dissolved oxygen balance are considered, the rate of variation of oxygen deficit over time can be expressed by the following differential equation, arising from the interaction of the deoxygenation and reaeration equations:

The parameters used in the Streeter-Phelps model are: River flow, upstream of the release $\left(Q_{r}\right)$; Sewage flow $\left(Q_{e}\right)$; Dissolved oxygen in the river upstream of the release $\left(D O_{r}\right)$; Dissolved oxygen in sewage $\left(O D_{e}\right)$; BOD5 in the river, upstream of the release $\left(B O D_{r}\right)$; Decomposition coefficient $\left(K_{d}\right)$; Reaeration coefficient $\left(K_{2}\right)$; River flow speed $(v)$; Travel time $(t)$; Concentration of saturation dissolved oxygen $\left(C_{S}\right)$; Minimum permissible dissolved oxygen ( $\left.D O_{\min }\right)$.

Eq. 1 is used to calculate the $D O$ concentration:

Knowing that:

$$
C_{t}=C_{s}-D_{t}
$$

DO deficit variation rate $=D O$ consumption $-D O$ production

$$
\begin{aligned}
& \frac{d D}{d t}=K_{d} \cdot L-K_{2} \cdot D \\
& \frac{d D}{d t}+K_{2} \cdot D=K_{d} \cdot L
\end{aligned}
$$

And $L$ is obtained from Eq. (5):

$$
\begin{aligned}
& \frac{d L}{d t}=-K_{d} \cdot L \\
& L=L_{0} \cdot e^{-K_{d} \cdot t}
\end{aligned}
$$

Replacing Eq. (6) in Eq. (4) we have:

$$
\frac{d D}{d t}+K_{2} \cdot D=K_{d} \cdot L_{0} \cdot e^{-K_{d} \cdot t}
$$


Multiplying Eq. (7) by $e^{K_{2} \cdot t}$ We have:

$$
\begin{aligned}
& \frac{d D}{d t} e^{K_{2} \cdot t}+K_{2} \cdot D \cdot e^{K_{2} \cdot t}=K_{d} \cdot L_{0} \cdot e^{-K_{d} \cdot t} e^{K_{2} \cdot t} \\
& \frac{d D}{d t} e^{K_{2} \cdot t}+K_{2} \cdot D \cdot e^{K_{2} \cdot t}=K_{d} \cdot L_{0} \cdot e^{\left(K_{2}-K_{d}\right) \cdot t} \\
& \frac{d D}{d t} e^{K_{2} \cdot t}+D \cdot \frac{d}{d t}\left(e^{K_{2} \cdot t}\right)=K_{d} \cdot L_{0} \cdot e^{\left(K_{2}-K_{d}\right) \cdot t} \\
& \frac{d}{d t}\left(D \cdot e^{K_{2} \cdot t}\right)=K_{d} \cdot L_{0} \cdot e^{\left(K_{2}-K_{d}\right) \cdot t} \\
& \int d\left(D \cdot e^{K_{2} \cdot t}\right)=\int K_{d} \cdot L_{0} \cdot e^{\left(K_{2}-K_{d}\right) \cdot t} d t \\
& \int d\left(D \cdot e^{K_{2} \cdot t}\right)=K_{d} \cdot L_{0} \int e^{\left(K_{2}-K_{d}\right) \cdot t} d t \\
& D \cdot e^{K_{2} \cdot t}=K_{d} \cdot L_{0} \cdot \frac{e^{\left(K_{2}-K_{d}\right) \cdot t}}{K_{2}-K_{d}}+C
\end{aligned}
$$

For instant zero $D=D_{0}$

$$
\begin{aligned}
& \text { D. } e^{K_{2} \cdot 0}=K_{d} \cdot L_{0} \cdot \frac{e^{\left(K_{2}-K_{d}\right) \cdot 0}}{K_{2}-K_{d}}+C \\
& C=D_{0}-\frac{K_{d} \cdot L_{0}}{K_{2}-K_{d}}
\end{aligned}
$$

Replacing Eq. (16) in Eq. (14) we have:

$$
\begin{aligned}
& D . e^{K_{2} \cdot t}=K_{d} \cdot L_{0} \cdot \frac{e^{\left(K_{2}-K_{d}\right) \cdot t}}{K_{2}-K_{d}}+D_{0}-\frac{K_{d} \cdot L_{0}}{K_{2}-K_{d}} \\
& D . e^{K_{2} \cdot t}=\frac{K_{d} \cdot L_{0}}{K_{2}-K_{d}}\left(e^{\left(K_{2}-K_{d}\right) \cdot t}-1\right)+D_{0} \\
& D=\frac{K_{d} \cdot L_{0}}{K_{2}-K_{d}}\left(e^{\left(K_{2}-K_{d}\right) \cdot t}-1\right) \cdot e^{-K_{2} \cdot t}+D_{0} \cdot e^{-K_{2} \cdot t} \\
& D=\frac{K_{d} \cdot L_{0}}{K_{2}-K_{d}}\left(e^{\left(K_{2}-K_{d}\right) \cdot t} e^{-K_{2} \cdot t}-e^{-K_{2} \cdot t}\right)+D_{0} \cdot e^{-K_{2} \cdot t} \\
& D=\frac{K_{d} \cdot L_{0}}{K_{2}-K_{d}}\left(e^{-K_{d} \cdot t}-e^{-K_{2} \cdot t}\right)+D_{0} \cdot e^{-K_{2} \cdot t}
\end{aligned}
$$

Where:

$$
D_{0}=C_{S}-C_{0}
$$

Soon we have:

$$
C_{t}=C_{S}-\left\{\frac{K_{d} \cdot L_{0}}{K_{2}-K_{d}} \cdot\left(e^{-K_{d} \cdot t}-e^{-K_{2} \cdot t}\right)+\left(C_{S}-C_{0}\right) \cdot e^{-K_{2} \cdot t}\right\}
$$

Eq. (1) to Eq. (23) represent the decay of organic matter and oxygen consumption, mediated by the reoxygenation reaction in which, through exogenous reactions, oxygen passes from the atmosphere to water. Considering a steady flow from the main course of the urban watershed.

Where: $d D$ : variation in the deficit of $D O$; $d_{t}=$ time variation; $K_{d}=$ BOD decay rate; $K_{a}=$ aeration rate; $L=B O D$ concentration; $L_{0}=$ initial $B O D$ concentration; $D_{0}=$ initial deficit $D O$; $C_{S}=$ concentration of saturation dissolved oxygen; $C_{0}=$ initial concentration oxygen after mixing $(\mathrm{mg} / \mathrm{L})$; $t=$ time. 
Calculation of the critical time of the Streeter-Phelps equation, considering the reaction kinetics

$$
\begin{aligned}
& \left.C_{t}=C_{S}-\left\{\frac{K_{d} \cdot L_{0}}{K_{2}-K_{d}} \cdot\left(e^{-K_{d} \cdot t}-e^{-K_{2} \cdot t}\right)+\left(C_{S}-C_{0}\right) \cdot e^{-K_{2} \cdot t}\right)\right\} \\
& C_{t}=C_{S}-\frac{K_{d} \cdot L_{0}}{K_{2}-K_{d}} \cdot e^{-K_{r} \cdot t}+\frac{K_{d} \cdot L_{0}}{K_{2}-K_{d}} \cdot e^{-K_{2} \cdot t}-\left(C_{S}-C_{0}\right) \cdot e^{-K_{2} \cdot t}
\end{aligned}
$$

To facilitate the calculations, we assumed in Eq. (25) that:

$$
a=\frac{K_{d} \cdot L_{0}}{K_{2}-K_{d}}
$$

Then we will have:

$$
C_{t}=C_{S}-a \cdot e^{-K_{d} \cdot t}+a \cdot e^{-K_{2} \cdot t}-\left(C_{S}-C_{0}\right) \cdot e^{-K_{2} \cdot t}
$$

For the calculation of the critical time we will apply the first derivative in Eq. (27) and equaling zero we will have:

$$
\begin{aligned}
& \frac{d C_{t}}{d t}=C_{S}-a \cdot e^{-K_{d} \cdot t}+a \cdot e^{-K_{2} \cdot t}-\left(C_{S}-C_{0}\right) \cdot e^{-K_{2} \cdot t}=0 \\
& \frac{d C_{t}}{d t}=0+a \cdot K_{d} \cdot e^{-K_{d} \cdot t_{c}}-a \cdot K_{2} \cdot e^{-K_{2} \cdot t_{c}}+K_{2} \cdot\left(C_{S}-C_{0}\right) \cdot e^{-K_{2} \cdot t_{c}}=0 \\
& a \cdot K_{d} \cdot e^{-K_{d} \cdot t_{c}}-K_{2} \cdot e^{-K_{2} \cdot t_{c}}\left[a-\left(C_{S}-C_{0}\right)\right]=0 \\
& t_{c} \cdot\left(K_{2}-K_{d}\right)=\ln K_{2} \cdot\left[a-\left(C_{S}-C_{0}\right)\right]-\ln \left(a \cdot K_{d}\right)=0 \\
& t_{c}=\frac{1}{\left(K_{2}-K_{d}\right)} \ln \left\{\left(\frac{K_{2}}{K_{d}}\right) \cdot\left[1-\frac{\left(C_{S}-C_{0}\right)}{a}\right]\right\}
\end{aligned}
$$

Replacing the value of ' $\boldsymbol{a}$ ' in Eq. (32) we have:

$$
t_{c}=\frac{1}{\left(K_{2}-K_{d}\right)} \ln \left\{\left(\frac{K_{2}}{K_{d}}\right) \cdot\left[1-\frac{\left(C_{S}-C_{0}\right) \cdot\left(K_{2}-K_{d}\right)}{K_{d} \cdot L_{0}}\right]\right\}
$$

\section{Enhanced DO-BOD model in the micro-watercourse}

The model of DO and BOD takes into account all natural phenomena interacting in a watercourse ranging in one direction (JHA et al., 2007).

$$
\frac{d D}{d t}=-K_{2} \cdot\left(C_{s}-C\right)+K_{d} \cdot L+S_{d}-F+R+R_{O 2 a m o n} \cdot\left(f_{n i t r} \cdot K_{a n}\right) \cdot N_{a m o n}
$$

From the Analytical Integration of the DO Deficit Eq. (34) we will have:

$$
\begin{aligned}
& D=\mathrm{D}_{\mathrm{o}} \cdot \mathrm{e}^{-\mathrm{K}_{2} \cdot \mathrm{t}} \\
& \text { Punctual deficit } \\
& +\frac{K_{d} \cdot L_{0}}{K_{2}-K_{r}} \cdot\left(e^{-K_{r} \cdot t}-e^{-K_{2} \cdot t}\right) \\
& \text { Punctual BOD } \\
& +\frac{R_{O 2 a m o n} \cdot K_{a n} \cdot N_{a m o n 0}}{K_{2}-K_{a n}} \cdot\left(e^{-K_{a n} \cdot t}-e^{-K_{2} \cdot t}\right) \quad \text { Nitrification } \\
& +S_{d \cdot}\left(1-e^{-K_{2} \cdot t}\right) \\
& \text { Sediment demand } \\
& -\frac{F}{K_{2}} \cdot\left(1-e^{-K_{2} \cdot t}\right) \\
& \text { Photosynthesis (variation of the primary production rate) } \\
& +\frac{R}{K_{2}} \cdot\left(1-e^{-K_{2} \cdot t}\right) \\
& \text { Respiration }
\end{aligned}
$$


$K_{d}=$ BOD decomposition coefficient $\left(\mathrm{d}^{-1}\right)$; $K_{r}=$ BOD removal coefficient by decomposition and sedimentation $\left(\mathrm{d}^{-1}\right)$; $K_{s}=$ BOD removal coefficient by decomposition $\left(\mathrm{d}^{-1}\right)$; $L=B O D$ last concentration in a travel time $t\left(\mathrm{mg} . \mathrm{L}^{-1}\right)$; $L_{o}=B O D$ last concentration of the mixture $\left(\mathrm{mg} . \mathrm{L}^{-1}\right)$;

$N_{a m o n}=\mathrm{N}$-ammonia concentration at any travel time $\mathrm{t}\left(\mathrm{mg} . \mathrm{L}^{-1}\right)$; $N_{a m o n o}=$ Initial $\mathrm{N}$-ammonia concentration (at the mixing point) $\left(\mathrm{mg} . \mathrm{L}^{-1}\right)$; $f_{\text {nitr }}=$ Correction factor of the nitrification coefficient as a function of $D O$; $R=$ Rate of oxygen consumption by respiration $\left(\mathrm{mgO}_{2} \cdot\left(\mathrm{m}^{3} \cdot \mathrm{d}\right)^{-1}\right)$; Rozamon $=$ Relationship between the oxygen consumed by each unit of oxidized ammonia $\left(\mathrm{mgO}_{2} \cdot \mathrm{mgNamon}^{-1}\right)$; $S d=$ Sediment oxygen demand $\left(\mathrm{mgO}_{2} .(\mathrm{L} . \mathrm{d})^{-1}\right)$; $T=$ Travel time (day).

\section{Calculation of critical time using Enhanced DO-BOD model in the micro-watercourse}

$$
\begin{gathered}
\left.C_{t}=C_{S}-\left\{\frac{K_{d} \cdot L_{0}}{K_{2}-K_{r}} \cdot\left(e^{-K_{r} \cdot t}-e^{-K_{2} \cdot t}\right)+\left(C_{S}-C_{0}\right) \cdot e^{-K_{2} \cdot t}\right)\right\}+\frac{R_{\text {Ozamon }} \cdot K_{a n} \cdot n_{a m o n 0}}{K_{2}-K_{a n}} \cdot\left(e^{-K_{a n} \cdot t}-e^{-K_{2} \cdot t}\right)+S_{d} \cdot(1- \\
\left.e^{-K_{2} \cdot t}\right)-\frac{F}{K_{2}} \cdot\left(1-e^{-K_{2} \cdot t}\right)+\frac{R}{K_{2}} \cdot\left(1-e^{-K_{2} \cdot t}\right)
\end{gathered}
$$

To facilitate the calculations, we will assume in Eq. (36) that:

$$
\begin{aligned}
& a=\frac{K_{d} \cdot L_{0}}{K_{2}-K_{r}} \\
& b=\frac{R_{\text {Ozamon }} \cdot K_{a n} \cdot n_{\text {amon } 0}}{K_{2}-K_{a n}}
\end{aligned}
$$

Replacing the values of ' $\boldsymbol{a}$ ' and ' $\boldsymbol{b}$ ' in Eq. (36) we have:

$$
\begin{gathered}
C_{t}=C_{S}-a \cdot e^{-K_{r} \cdot t}+a \cdot e^{-K_{2} \cdot t}-\left(C_{S}-C_{0}\right) \cdot e^{-K_{2} \cdot t}+b \cdot e^{-K_{a n} \cdot t}-b \cdot e^{-K_{2} \cdot t}+S_{d}-S_{d} \cdot e^{-K_{2} \cdot t}-\frac{F}{K_{2}}+ \\
\frac{F}{K_{2}} \cdot e^{-K_{2} \cdot t}+\frac{R}{K_{2}}-\frac{R}{K_{2}} \cdot e^{-K_{2} \cdot t}
\end{gathered}
$$

Applying the first derivative in Eq. (39) we have:

$$
\begin{aligned}
& \frac{d C_{t}}{d t}=C_{S}-a \cdot e^{-K_{r} \cdot t}+a \cdot e^{-K_{2} \cdot t}-\left(C_{S}-C_{0}\right) \cdot e^{-K_{2} \cdot t}+b \cdot e^{-K_{a n} \cdot t}-b \cdot e^{-K_{2} \cdot t}+S_{d}-S_{d} \cdot e^{-K_{2} \cdot t}-\frac{F}{K_{2}}+ \\
& \quad \frac{F}{K_{2}} \cdot e^{-K_{2} \cdot t}+\frac{R}{K_{2}}-\frac{R}{K_{2}} \cdot e^{-K_{2} \cdot t}=0 \\
& \frac{d C_{t}}{d t}=0+a \cdot K_{r} \cdot e^{-K_{r} \cdot t_{c}}-a \cdot K_{2} \cdot e^{-K_{2} \cdot t_{c}}+K_{2} \cdot\left(C_{S}-C_{0}\right) \cdot e^{-K_{2} \cdot t_{c}}-b \cdot K_{a n} \cdot e^{-K_{a n} t_{c}}+b \cdot K_{2} \cdot e^{-K_{2} \cdot t_{c}}+ \\
& \quad S_{d} \cdot K_{2} \cdot e^{-K_{2} t_{c}}-F \cdot e^{-K_{2} \cdot t_{c}}+R \cdot e^{-K_{2} \cdot t_{c}}=0 \\
& \text { a. } K_{r} \cdot e^{-K_{r} \cdot t_{c}}-K_{2} \cdot e^{-K_{2} \cdot t_{c}}\left[a-\left(C_{S}-C_{0}\right)\right]-b \cdot K_{a n} \cdot e^{-K_{a n} t_{c}}+b \cdot K_{2} \cdot e^{-K_{2} \cdot t_{c}}-K_{2} \cdot e^{-K_{2} \cdot t_{c}} \cdot\left[-S_{d}+\frac{F}{K_{2}}-\right.
\end{aligned}
$$

$$
\left.\frac{R}{K_{2}}\right]=0
$$

Let us assume in Eq. (42) that:

$$
c=\left[-S_{d}+\frac{F}{K_{2}}-\frac{R}{K_{2}}\right]
$$

Applying the logarithm property in Eq. (42) we have:

$$
\begin{gathered}
\ln \left(a \cdot K_{r} \cdot e^{-K_{r} \cdot t_{c}}\right)-\ln \left\{K_{2} \cdot e^{-K_{2} \cdot t_{c}}\left[a-\left(C_{S}-C_{0}\right)\right]\right\}-\ln \left(b \cdot K_{a n}\right)-\ln \left(e^{-K_{a n} t_{c}}\right)+\ln \left(b \cdot K_{2}\right)+\ln \left(e^{-K_{2} \cdot t_{c}}\right)- \\
\ln \left(c \cdot K_{2}\right)-\ln \left(e^{-K_{2} \cdot t_{c}}\right)=0 \\
\ln \left(a \cdot K_{r}\right)-\left(K_{r} \cdot t_{c}\right)+\left(K_{2} \cdot t_{c}\right)+\left(K_{a n} t_{c}\right)-\left(K_{2} \cdot t_{c}\right)+\left(K_{2} \cdot t_{c}\right)-\ln K_{2} \cdot\left[a-\left(C_{S}-C_{0}\right)\right]-\ln \left(b \cdot K_{a n}\right)+ \\
\ln \left(b \cdot K_{2}\right)-\ln \left(c \cdot K_{2}\right)=0 \\
t_{c} \cdot\left(K_{a n}+K_{2}-K_{r}\right)=\ln K_{2} \cdot\left[a-\left(C_{S}-C_{0}\right)\right]-\ln \left(a \cdot K_{r}\right)+\ln \left(b . K_{a n}\right)-\ln \left(b . K_{2}\right)+\ln \left(c . K_{2}\right)
\end{gathered}
$$


Replacing the value of ' $c$ ' in Eq. (46) we have:

$$
t_{c}=\frac{1}{\left(K_{a n}+K_{2}-K_{r}\right)}\left\langle\ln \left\{\left(\frac{K_{2}}{K_{r}}\right) \cdot \frac{\left[a-\left(C_{S}-C_{0}\right)\right]}{a}\right\}+\ln \left(\frac{K_{a n}}{K_{2}}\right)-\ln \left(S_{d} \cdot K_{2}\right)+\ln (F)-\ln (R)\right\rangle
$$

Replacing the value of ' $\boldsymbol{a}$ ' in Eq. (42) we have:

$$
t_{c}=\frac{1}{\left(K_{a n}+K_{2}-K_{r}\right)}\left\{\ln \left\{\left(\frac{K_{2}}{K_{r}}\right) \cdot\left[1-\frac{\left(C_{S}-C_{0}\right) \cdot\left(K_{2}-K_{r}\right)}{K_{d} \cdot L_{0}}\right]\right\}+\ln \left(\frac{K_{a n}}{K_{2}}\right)-\ln \left(S_{d} \cdot K_{2}\right)+\ln (F)-\ln (R)\right\}
$$

Eq. 48 shows that, if the terms referring to nitrification, sedimentation, photosynthesis and respiration are disregarded, the equation is equal to the Streeter-Phelps equation for the calculation of critical time Eq. (33).

\section{Model calibration}

The calibration of a mathematical model of water quality consists of adapting the parameters of the equation to the real world, considering the physical, chemical and biological variables of this environment, adjusting the data estimated in the modeling with the data observed in the field (TONON, 2014). For the calibration of the mathematical model presented in this work, experimental data of travel time $(\boldsymbol{t})$ and dissolved oxygen $(D O)$ were used. The travel time was transformed into days through Eq. (49) in each of the six sampling sections as a function of the distance traveled and the speed of the watercourse, considering average speed values along the watercourse.

$$
t=\frac{d}{v .86400}
$$

Where:

\section{Calibration of the Streeter-Phelps mathematical model}

The methodology for obtaining the three adjustable coefficients $\left(K_{d} \cdot L_{0}, K_{d}\right.$ and $\left.K_{2}.\right)$ of Eq. (23) consisted of using the experimental data of dissolved oxygen (DO) and the water flow travel time (t) measured in the six sampling sections as input data in the model. The coefficient adjustments were made using the software Curve Expert version 1.4, using the mathematical method of adjusting nonlinear functions of Levenberg-Marquardt. The mathematical method of adjusting nonlinear functions requires an initial estimate of its coefficients to be adjusted to start the interactive process of adjusting a function.

The experimental values of oxygen concentration at saturation and initial oxygen deficit were respectively $8.33 \mathrm{mg} / \mathrm{L}$ and $2.22 \mathrm{mg} / \mathrm{L}$. As in Eq. (23) we have the product $K_{d} . L_{0}$ which are two coefficients multiplied by each other, which makes it impossible to adjust the two coefficients simultaneously, so we decided to name it $\beta=K_{d} \cdot L_{0}$ and use only $\beta$ as the coefficient to be adjusted.

The selection criterion of uncertainty analysis (RINALDI et al., 1978; 1979; BECK, 1987; MCCUTCHAN, et al., 1998; MENEZES et al., 2016) to verify the uncertainties associated with the models it was obtained from the joint analysis of Pearson's correlation Eq. (50), the sum of the mean deviations Eq. (51) and the sum 
of quadratic deviations Eq. (52).

Pearson correlation

$R^{2}=\frac{\sum\left(x_{i}-\bar{x}_{l}\right) \cdot\left(\sum y_{i}-\overline{y_{l}}\right)}{\sqrt{\sum\left(x_{i}-\bar{x}_{l}\right)^{2} \sum\left(y_{i}-\overline{y_{l}}\right)^{2}}}$

The sum of the mean deviations

$D m=\frac{1}{n} \sum_{1}^{n}\left|y_{i}-\bar{y}_{l}\right|$

The sum of the quadratic deviations is given by

$D q=\sum_{1}^{n}\left(y_{i}-\bar{y}_{l}\right)^{2}$

\section{Calibration of the Improved DO-BOD Model in the micro-watercourse}

The six coefficients: $S_{d}, F, R, \alpha, K_{a n}$ e $K_{r}$ were adjusted using the software Curve Expert version 1.4, using the same methodological procedure described in item 2.4.1.

The experimental values of oxygen concentration in saturation and initial oxygen deficit were the same as those used in item 2.4.1. In the complete model, the values of the coefficients $K_{d} \cdot L_{0}, K_{d}$ and $K_{2}$ obtained from the adjustment of the Streeter-Phelps model presented in item 2.4.1 were used as input data. In the nitrification term of Eq. (35), it was assigned that $\alpha=R_{\text {O2amon }} \cdot K_{a n} \cdot N_{\text {amono }}$ taking into account the same criteria for the product $K_{d} \cdot L_{0}$ set out in item 2.4.1 obtained in Von Sperling (2014). The value of the coefficient $K_{S}$ comes from the difference between the coefficients $K_{r}$ and $K_{d}$ obtained by adjusting Eq. (35) to the experimental data.

\section{Prediction of Critical Properties $\left(t_{c} \mathbf{D O}_{c}\right.$ and $\left.d_{c}\right)$ using the Sreet-Phelps model and the complete DO and BOD model}

For the prediction of critical properties, it was considered $K_{1}=K_{d}$ (obtained by adjusting to the Streeter-Phelps mathematical model). The $L_{0}$ was determined by dividing the $\beta$ coefficient by the $K_{d}$ both obtained from the adjustment of the Streeter-Phelps model to the experimental data. $K_{1}$ may vary with the type of organic matter, degree of treatment, temperature and inhibitory substances as suggested by Von Sperling (2005).

The following values were used to determine the critical parameters in the two models: $C_{s}=$ $8.3 \mathrm{mg} / \mathrm{L} ; K_{d}=4.82 \mathrm{day}^{-1} ; K_{2}=4.57 \mathrm{day}^{-1} ; L_{0}=7.82 \mathrm{mg} / \mathrm{L}$ and $v=0.18 \mathrm{~m} / \mathrm{s}$.

To determine the critical parameters of the two models, the following values were used: $C_{s}=$ 8.3; $K_{d}=4.82 ; K_{2}=4.57 ; L_{0}=7,82$ e $v=0.18 \mathrm{~m} / \mathrm{s}$. The $t c$ values were determined using Equations 33 for the prediction using the Streeter-Phelps model and through Eq. (48) for the prediction using the improved DO-BOD model. The calculation of $D O_{c}$ and $d_{c}$ were determined using Eq. (53) and Eq. (54), respectively.

$$
\begin{aligned}
& O D_{c}=C_{s}-\frac{K_{d}}{K_{2}} \cdot L_{0} \cdot e^{-K_{d} \cdot t_{c}} \\
& d_{c}=t_{c} \cdot v \cdot 86.4
\end{aligned}
$$

For the prediction of accumulated oxygen consumption (exerted BOD) the maximum value found was $7.83 \mathrm{mg} / \mathrm{L}$ in the initial section and the minimum of $1.38 \mathrm{mg} / \mathrm{L}$ in the last section. 


\section{RESULTS AND DISCUSSION}

Considering, the main of the watercourse observed, in this study, has low depth, low average flow and narrow width, in addition to a small extension, it is feasible to weigh the estimate of dissolved oxygen values and biological oxygen demand in different sections of the main course in order to test the applicability of the two models.

It is important to remember that the adjustments to the Streeter-Phelps models and to the improved DO-BOD model, in this study, were made considering only experimental data on the dissolved oxygen variable. Another aspect is that we opted for analytical solutions of the expressions, although Cunha et al. (2019) remember the essential correlation of dissolved oxygen in the decomposition of organic matter.

\section{Mathematical modeling}

Table 2 shows the values of the three coefficients of the Streeter-Phelps mathematical model Eq. (23) adjusted to the experimental data of travel time versus DO.

Table 2: Coefficients of the Streeter-Phelps mathematical model adjusted to the experimental data of travel time/DO.

\begin{tabular}{ll}
\hline Coefficients & Adjusted parameters \\
\hline $\mathrm{B}$ & 37.74 \\
$K_{2}$ & 4.57 \\
$K_{d}$ & 4.82 \\
\hline
\end{tabular}

Table 3 shows the values of the six coefficients of the complete mathematical model of DO and BOD adjusted from the experimental data of travel time versus DO. The coefficients were used in Eq. (35), considering all terms of the equation: punctual deficit and punctual BOD, nitrification, sediment demand, photosynthesis and respiration.

Table 3: Coefficients of the complete mathematical model of DO and BOD adjusted to the experimental data of travel time/DO.

\begin{tabular}{ll}
\hline Coefficients & Adjusted parameters \\
\hline$S_{d}$ & 1.93 \\
$F$ & 4.3 \\
$R$ & 0.2 \\
$\alpha$ & 0 \\
$K_{a n}$ & 2.5 \\
$K_{r}=K_{s}+K_{d}$ & 3.79 \\
\hline
\end{tabular}

In this work based on the adjusted coefficients presented in Table 2 and Table 3, it was possible to estimate through the Streeter-Phelps model and improved of DO and BOD Model, the values of critical time, critical distance and critical DO along the water body course.

Table 4 shows the critical time $\left(C_{t}\right)$, critical distance $\left(C_{d}\right)$ and critical DO $\left(D O_{c}\right)$ obtained through Eq. (33) and Eq. (48) using the Streeter-Phelps model and improved of DO and BOD Model, respectively. The critical parameters are fundamental to identify the decay level of dissolved oxygen along the watercourse of the micro-watershed. Thus, providing the means to diagnose the impairment degree of the water body and giving necessary subsidies to environmental agencies for decision-making and mitigating intervention measures, aiming at spring recovery through effluent treatment. 
Table 4: Critical parameters estimated from the coefficients of mathematical models adjusted to the experimental data.

\begin{tabular}{llll} 
Model & $\begin{array}{l}\text { Critical time }\left(C_{t}\right) \\
(\text { day) }\end{array}$ & $\begin{array}{l}\text { Critical Distance }\left(\boldsymbol{C}_{d}\right) \\
(\mathrm{Km})\end{array}$ & $\begin{array}{l}\text { Critical DO }\left(\mathbf{D O} O_{c}\right) \\
(\mathbf{m g} / \mathrm{L})\end{array}$ \\
\hline Streeter-Phelps & 0.15 & 2.41 & 4.38 \\
Improved DO-BOD model & 0.13 & 2.03 & 3.90 \\
\hline
\end{tabular}

In Figure 2 shows the experimental DO deficit graph, the DO deficit predicted through the StreeterPhelps model Eq. (23) and the DO deficit predicted by the improved DO-BOD model Eq. (35) along the Urumari micro-watercourse regarding the following hypotheses: A) Using the complete equation with all terms; B) Using the terms of punctual deficit and punctual BOD plus the term nitrification (N); C) Using the terms of item ' $\boldsymbol{b}$ ' plus the term sediment demand (SD); D) Using the terms of item ' $\boldsymbol{c}$ ' plus the term Photosynthesis (P); E) Using the terms of item ' $\boldsymbol{d}$ ' plus the term Respiration.

The objective of these hypotheses was to evaluate which scenario best correlates the experimental data using as a selection criterion, for the sensitivity analysis the hypothesis that presented the smallest deviations determined by Eq. (50), Eq. (51) and Eq. (52) through a sensitivity analysis

In Figure 2, the graphs of the DO deficit determined by the improved DO-BOD model, were obtained through Eq. (35) using the coefficients adjusted to the experimental data presented in Table 3 and considering the coefficients presented in Table 2 as described in item 2 as input data. 2.4.2.

The graphs presented in Figure 2 referring to the hypothesis terms of item ' $\boldsymbol{a}$ ' and ' $\boldsymbol{b}$ ' using the complete equation with all terms and the equation with the point deficit and point BOD terms plus the nitrification term $(\mathrm{N})$ overlap because as the parameter $\alpha=0$ the predicted values for the DO deficit are the same for both equations.

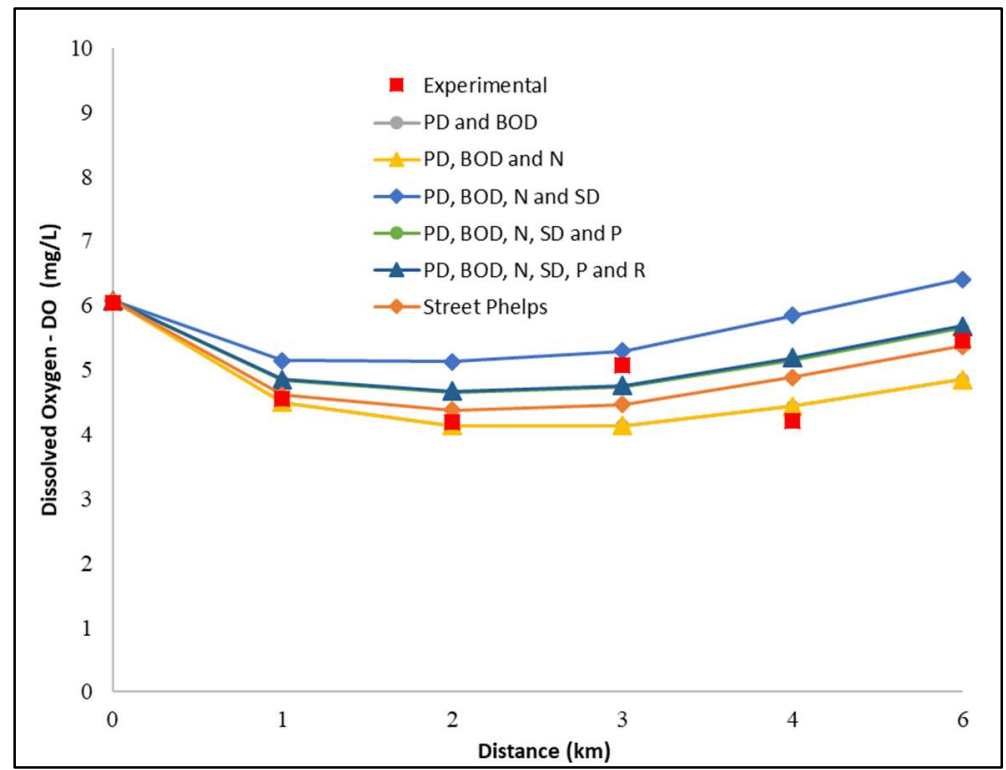

Figure 2: Dissolved oxygen decay curve as a function of watercourse distance using the complete model of DO and BOD. PD = Punctual Deficit; BOD = Biochemical Oxygen Demand; SD = Sediment Demand; $\mathbf{N}=$ Nitrification; SD =Sedimentation Demand; $\mathbf{P}=$ Photosynthesis; $\mathbf{R}=$ Respiration

We observed that hypothesis ' $\boldsymbol{c}$ ' (DP and BOD + Nitrification (N) + Sediment demand (DS) did not satisfactorily correlate the experimental data, which as suggested by Jha et al. (2007) could infer that the colloidal material was rapidly coagulated and removed after domestic sewage enters the watercourse. 
Table 5 shows through uncertainty analysis that of the five evaluated hypotheses only the hypothesis ' $\boldsymbol{c}$ ' (PD and BOD + Nitrification (N) + Sediment demand (SD), did not satisfactorily correlate the experimental data, due to presenting a low Pearson correlation value $\left(R^{2}=0.63\right)$ since the correlation coefficient is the most important parameter in the uncertainty analysis for the selection of the best fit to the experimental data.

The Streeter-Phelps model presented the best correlation to the experimental data with the values of $\mathrm{R}^{2}$ equal to 0.83; Mean deviations (MDs) equal to 0.56 and Quadratic deviation (Qd) equal to 4.98, respectively. Table 5 shows that the deviations from the other four hypotheses did not present significant differences when compared to the Streeter-Phelps model, however, the Streeter-Phelps model should be used for the mathematical modeling of the Urumari micro-watershed because it is a simpler model and presents a smaller number of adjustable parameters.

Table 5: Pearson correlation values, absolute mean deviations and quadratic deviations for Streeter-Phelps mathematical models and for the hypotheses of the complete model of DO and BOD.

\begin{tabular}{|c|c|c|c|c|}
\hline \multirow[b]{2}{*}{ Hypotheses } & \multirow[b]{2}{*}{ Mathematical model } & \multicolumn{3}{|l|}{ Deviations } \\
\hline & & $\begin{array}{l}\text { Pearson's } \\
\text { correlation } \mathbf{R}^{2}\end{array}$ & $\begin{array}{l}\text { Mean } \\
\text { deviations } \\
\text { (MDs) }\end{array}$ & $\begin{array}{l}\text { Quadratic } \\
\text { deviation }(Q d)\end{array}$ \\
\hline$a$ & Streeter-Phelps & 0.83 & 0.56 & 4.98 \\
\hline$b$ & Punctual Deficit (PD) and BOD Punctual Deficit (BOD) & 0.82 & 0.58 & 5.59 \\
\hline$c$ & DP e BOD + Nitrification $(\mathrm{N})$ & 0.82 & 0.58 & 5.59 \\
\hline$d$ & $\begin{array}{l}\text { DP e BOD + Nitrification }(N)+\text { Sedimentation Demand } \\
(\mathrm{SD})\end{array}$ & 0.63 & 0.57 & 5.83 \\
\hline$e$ & $\begin{array}{l}\text { DP e BOD + Nitrification (N) + Sedimentation Demand } \\
(\mathrm{SD})+\text { Photosynthesis }(P)\end{array}$ & 0.81 & 0.53 & 4.61 \\
\hline$f$ & $\begin{array}{l}\text { DP e BOD + Nitrification (N) + Sedimentation Demand } \\
(\mathrm{SD})+\text { Photosynthesis }(P)+\text { Respiration }(R)\end{array}$ & 0.81 & 0.53 & 4.62 \\
\hline
\end{tabular}

In Figure 3, if we analyze the prediction of the remaining BOD, we can observe that the initial value is zero and grows exponentially until reaching a maximum value of $6.45 \mathrm{mg} / \mathrm{L}$ in the last section (of the remaining BOD), a similar result was found by Santos et al. (2020) in an urban watershed in the same municipality. Thus, we can observe that the Urumari micro-watershed presents good water oxygenation, mainly justified by the low concentration of remaining BOD according to predicted values, with concentrations ranging from 0 to $6.15 \mathrm{mg} / \mathrm{L}$ (Figure 3) also cited by Santos et al. (2020). The result of low remaining $\mathrm{BOD}$ concentrations was already expected, since there is no source of organic contamination around the first sampling sections. The low BOD concentration in the sampling sections 4,5 and 6 within the urban area indicates the preservation of environmental quality.

In Figure 3 shows the graphs of the remaining BOD $(L)$ and exerted BOD $(y)$ as a function of the distance of the watercourse determined by Eq. (55) and Eq. (56), respectively. We observed that the intersection Eq. (57) between the two equations occurs in $t=0.14$ day $^{-1} ; d=2.24 \mathrm{Km}$ and $L=y=$ $3.91\left(\mathrm{mg} \frac{\mathrm{O}_{2}}{\mathrm{~L}}\right)$ assuming that $K_{1}=K_{d}$. At this point we can observe the similarity of these parameters with the critical parameters presented in Table 4, we can infer that at this very moment where the two curves intersect, the accumulated oxygen consumption equals the remaining amount of organic matter and at this very moment we have the critical conditions of the process.

$$
L=L_{0} \cdot e^{-k_{1} \cdot t}
$$




$$
\begin{aligned}
& y=L_{0} \cdot\left(1-e^{-k_{1} \cdot t}\right) \\
& t=\frac{\ln (2)}{K_{1}}
\end{aligned}
$$

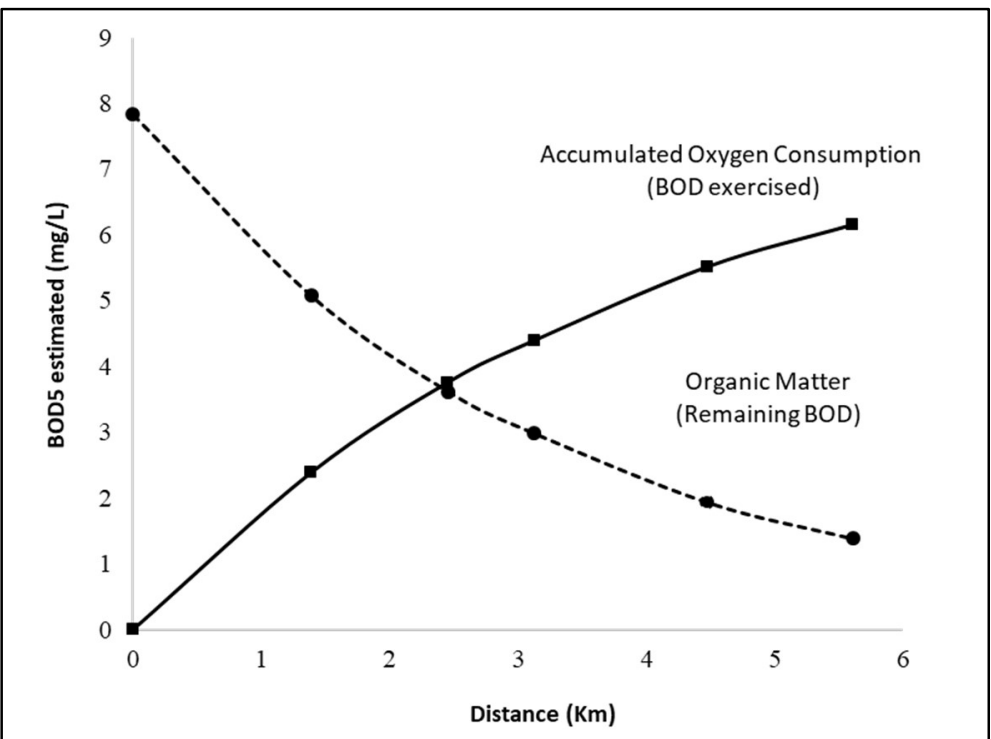

Figure 3: Graph of the exerted BOD versus the remaining BOD predicted as a function of the parameters adjusted to the experimental data.

\section{CONCLUSIONS}

Streeter-Phelps mathematical model was the one that best correlated the experimental data and it can be used to simulate or extrapolate scenarios of DO deficit at any distance along the watershed with no need to measure chemical or physical variables in any collection site. Thus, providing the means to diagnose the impairment degree of the water body and giving necessary subsidies to environmental agencies for decision-making and intervention mitigation measures aiming at spring recovery.

ACKNOWLEDGMENT: Acknowledgments to the Municipal Secretariat for the Environment - SEMMA of the City of Santarém for financial resources to support the Project 'Integrated Actions and Socio-Environmental Quality Project of Igarapé do Urumari', granted to the Foundation for Amazonian Integration - FIAM through Contract №. 012/2017 - SEMMA.

\section{REFERENCES}

ANA. Agência Nacional de Águas. Atlas esgotos: despoluição de bacias hidrográficas. Brasília: ANA, 2017.

ANTUNES, S.; PINTO, F.. Biomanipulação para o controlo da eutrofização. Revista de Ciência Elementar, Porto, v.8, n.1, 2020. DOI: http://doi.org/10.24927/rce2020.010

ARAGÃO, J. D. S.; BORGES, J. T.. A busca pela universalização do abastecimento de água e esgotamento sanitário: evolução, desafios e perspectiva. Um estudo de caso em Manaus-AM. Novos Cadernos NAEA, Belém, v.21, n.3, 2018. DOI: http://doi.org/10.5801/ncn.v13i3.4974

BECK, M. B.. Water quality modeling: A review of the analysis of uncertainty. Water Resources Research, New Jersey, v.23, n.8, p.1393-1442, 1987. DOI: http://doi.org/10.1029/WR023i008p01393
PRAJAPATI, U. B.; DWIVEDI, A. K.. Free Oxygen Budget of a Polluted Tropical River. Journal of Waste Water Treatment \& Analysis, Brussels, v.7, n.2, 2016. DOI: http://doi.org/10.4172/2157-7587.1000235

CARDOSO, C. M. M.; CARDOSO, N. C. V. F. M.; MENDONÇA, A. R. V.; PEDROZA, M. M.; VIEIRA, G. E. G.; OLIVEIRA, J. D.. Quantificação da matéria orgânica em rios da Amazônia Brasileira sob a influência de resíduos da indústria de curtume. Revista AIDIS de Ingeniería y Ciencias Ambientales. Investigación, desarrollo y práctica, Cidade do México, v.11, n.2, p.153-166, 2018. DOI: http://dx.doi.org/10.22201/iingen.0718378xe.2018.11.2.583 $\underline{65}$ 
CUNHA, C. L. N.; FERREIRA, A. P.. Modelagem matemática para avaliação dos efeitos de despejos orgânicos nas condições sanitárias de águas ambientais. Cadernos de Saúde Pública, Rio de Janeiro, v.22, n.8, p.1715-1725, 2006. DOI: http://doi.org/10.1590/S0102-311X2006000800020

CUNHA, C. L. N.; FERREIRA, A. P.. Critical analysis by comparison between water quality models applied to polluted rivers: Contributions to health, water and sanitation. Engenharia Sanitária e Ambiental, Rio de Janeiro, v.24, n.3, p.473-480, 2019. DOI: http://doi.org/10.1590/s1413-41522019112332

FAN, C.; KO, C. K.; WANG, W. S.. An Innovative Modeling Approach Using Qual2K and HEC-RAS Integration to Assess the Impact of Tidal Effect on River Water Quality Simulation. Journal of Environmental Management, Amsterdam, v.90, n.5, p.1824-1832, 2009. DOI: http://doi.org/10.1016/j.jenvman.2008.11.011

GHAHRAMANI, A.; FREEBAIRN, D. M.; SENA, D. R.; CUTAJAR, J. L.; SILBURN, D. M.. A pragmatic parameterisation and calibration approach to model hydrology and water quality of agricultural landscapes and catchments. Environmental Modelling \& Software, Amsterdam, v.22, n.8, p.104733, 2020. DOI: http://doi.org/10.1016/i.envsoft.2020.104733

GUO, M.; JIANG, Z.; BU, Y.; CHENG, J.. Supporting sustainable development of water resources: A social welfare maximization game model. International Journal of Environmental Research and Public Health, Basel, v.16, n.16, 2019. DOI: http://doi.org/10.3390/ijerph16162896

JHA, R.; OJHA, C. S.; BHATIA, K. K.. Development of Refined $B O D$ and DO Models for Highly Polluted Kali River in India. Journal of Environmental Engineering, Reston, v.133, n.8, p.839-852, 2007. DOI: http://doi.org/10.1061/(ASCE)07339372(2007)133:8(839)

LONG, B. T.. Inverse algorithm for Streeter-Phelps equation in water pollution control problem. Mathematics and Computers in Simulation, Amsterdam, v.171, p.119-126, 2020. DOI: http://doi.org/10.1016/j.matcom.2019.12.005

MANNINA, G.; VIVIANI, G.. Water quality modelling for ephemeral rivers: Model development and parameter assessment. Journal of Hydrology, Amsterdam, v.393, n.3-4, p.186-196, 2010. DOI: http://doi.org/10.1016/j.jhydrol.2010.08.015

MCCUTCHAN, J. H.; LEWIS, W. M.; SAUNDERS, J. F.. Uncertainty in the Estimation of Stream Metabolism from Open-Channel Oxygen Concentrations. Journal of the North American Benthological Society, Chicago, v.17, n.2, p.155164, 1998. DOI: http://doi.org/10.2307/1467959

MENDES, D. A. R.. Aplicação do modelo QUAL2Kw para avaliação da capacidade de assimilação de cargas pontuais no Rio Itapanhaú. Tese (Doutorado em Meio Ambiente e Recursos Hídricos) - Universidade de São Paulo, São Paulo, 2010. DOI: http://doi.org/10.11606/D.3.2010.tde-17082010$\underline{111717}$

MENEZES, J. P. C.; OLIVEIRA, L. F. C.; SALLA, M. R.. Incertezas sobre a modelagem matemática de qualidade da água em curso de água Urbano. Ciencia y Engenharia, Science and Engineering Journal, Uberlândia, v.25, n.2, p.1-8, 2016. DOI: http://doi.org/10.14393/19834071.2016.34404

PETERS, N. E.; MEYBECK, M.. Water Quality Degradation Effects on Freshwater Availability: Impacts of Human Activities. Water International, Londres, v.25, n.2, p.185193, 2000. DOI:

http://doi.org/10.1080/02508060008686817

RINALDI, S.; SONCINI-SESSA, R.. Sensitivity analysis of generalized Streeter-Phelps models. Advances in Water Resources, Amsterdam, v.1, n.3, p.141-146, 1978. DOI: http://doi.org/10.1016/0309-1708(78)90024-6

RINALDI, S.; SONCINI-SESSA, R.; STEHFEST, H.; TAMURA, H.. Modeling and control of river quality. New York: McGrawHill, 1979.

SANTOS, R. F.; SANTOS, Z.; SOUSA, M. S.; LOPES, R. B.; MOURA, L. S.. Modelagem matemática da autodepuração da microbacia do Irurá no município de Santarém - Pará. Revista Tecnologia, Fortaleza, v.41, n.1, p.1-14, 2020. DOI: http://dx.doi.org/10.5020/23180730.2020.10275

STREETER, H. W.; PHELPS, E. B.. A Study of the Pollution and Natural Purification of the Ohio River, III, Factors Concerned in the Phenomena of Oxidation and Reaeration. Public Health Bulletin, Washingt, v.146, p.75, 1925.

TEODORO, A.; IDE, C. N.; RIBEIRO, M. L.; BROCH, S. A. O. SILVA, J. D.. Implementação do conceito Capacidade de Diluição de Efluentes no modelo de qualidade da água QUAL-UFMG: estudo de caso no Rio Taquarizinho (MS). Engenharia Sanitária e Ambiental, Rio de Janeiro, v.18, n.3, p.275-288, 2013. DOI: http://doi.org/10.1590/S1413$\underline{41522013000300010}$

TONON, K.. Modelagem da qualidade da água utilizando os modelos Streeter-Phelps e QUAL-UFMG na Bacia do Rio Lambari-Poços de Caldas. Dissertação (Mestrado em Ciência e Engenharia Ambiental) - Universidade Federal de Alfenas, Poços de Caldas, 2014.

VON SPERLING, M.. Introdução à qualidade das águas e ao tratamento de esgotos. Belo Horizonte: UFMG, 2005.

VON SPERLING, M.. Estudos e modelagem da qualidade da água de rios. 2 ed. Belo Horizonte: Universidade Federal de Minas Gerais, 2014

YOSHII, M. P. C.; CETRULO, T. B.; MALHEIROS, T. F.. Boas práticas para a universalização dos serviços de abastecimento de água e esgotamento sanitário: estudo de caso no município de Piracicaba SP. Revista DAE, São Paulo v.67, n.219, p.115-127, 2019. DOI: http://doi.org/10.4322/dae.2019.049

ZHANG, X.; LUO, J.; ZHANG, X.; XIE, J.. Dynamic simulation of river water environmental capacity based on the subsection summation model. Water Environment Research, New Jersey, v.92, n.2, p.278-290, 2020. DOI: http://doi.org/10.1002/wer.1242

A CBPC - Companhia Brasileira de Produção Científica (CNPJ: 11.221.422/0001-03) detém os direitos materiais desta publicação. Os direitos referem-se à publicação do trabalho em qualquer parte do mundo, incluindo os direitos às renovações, expansões e disseminações da contribuição, bem como outros direitos subsidiários. Todos os trabalhos publicados eletronicamente poderão posteriormente ser publicados em coletâneas impressas sob coordenação da Sustenere Publishing da Companhia Brasileira de Produção Científica e seus parceiros autorizados. Os (as) autores (as) preservam os direitos autorais, mas não têm permissão para a publicação da contribuição em outro meio, impresso ou digital, em português ou em tradução. 